\title{
NOTEXIN PREFERENTIALLY INHIBITS THE RELEASE OF NEWLY SYNTHESIZED ACETYLCHOLINE FROM RAT BRAIN SYNAPTOSOMAL FRACTIONS
}

\author{
CAMERON B. GUNDERSEN ${ }^{2}$ AND DONALD J. JENDEN
}

Department of Pharmacology, School of Medicine, University of California, Los Angeles, California 90024

\begin{abstract}
An investigation was made of the effects of the snake venom neurotoxin, notexin, on acetylcholine turnover in rat brain $\mathrm{P}_{2}$ fractions using a gas chromatographic mass spectrometric assay for acetylcholine and choline. In contrast to earlier reports, we found a stimulation of the uptake and acetylation of labeled choline by toxin-treated $\mathrm{P}_{2}$ fractions. More significantly, notexin inhibited the release of this newly synthesized transmitter. These effects were found to be dependent on the dose of the toxin and the time of exposure of the $\mathrm{P}_{2}$ fraction to notexin. Longer exposure to notexin or experiments involving resuspension of notexin-treated $\mathrm{P}_{2}$ fractions appeared to result in considerable lysis of the transmitter-containing particles. Thus, notexin may alter acetylcholine compartmentation in the nerve ending and thereby affect acetylcholine synthesis.
\end{abstract}

Notexin belongs to a class of presynaptically acting snake venom neurotoxins which have phospholipase $A_{2}$ activity (for reviews, see Lee, 1979; Howard and Gundersen, 1980). These toxins, including $\beta$-bungarotoxin, crotoxin, notexin, and taipoxin, have been shown to have similar effects on the electrophysiological properties of transmitter release and on the ultrastructure of motor nerve terminals (Cull-Candy et al., 1976; Chang et al., 1977; Magazanik and Slavnova, 1978). Neurochemical studies have demonstrated that notexin is a potent inhibitor of the high affinity choline (Ch) transport system of Torpedo t-sacs (Dowdall et al., 1977) and of rat brain crude synaptosome $\left(\mathrm{P}_{2}\right)$ fractions (Sen et al., 1978). A similar inhibitory effect has been reported for the other phospholipase $\mathrm{A}_{2}$ neurotoxins (Dowdall et al., 1977; Sen et al., 1976). However, in a recent comparison of the actions of $\beta$-bungarotoxin and notexin on cholinergic parameters of rat brain $\mathrm{P}_{2}$ fractions (Gundersen and Jenden, 1981), we observed no decline of high affinity $\mathrm{Ch}$ transport in $\mathrm{P}_{2}$ fractions treated with notexin. In fact, at the dose employed, notexin appeared to stimulate $\mathrm{Ch}$ uptake and acetylcholine (ACh) synthesis (Gundersen and Jenden, 1981). This investigation represents a more detailed study of the effects of notexin on ACh turnover in rat brain $\mathbf{P}_{2}$ fractions.

\footnotetext{
'We thank Dr. Struan Sutherland for the kind gift of purified notexin. Esther Shaw provided excellent technical assistance and Flo Comes offered valuable editorial comment. This work was supported in part by United States Puhlic Health Service Grant MH-17691.

" To whom correspondence should be addressed at his current address, Department of Biophysics, University College London, London WC1E 6BT, England.
}

\section{Materials and Methods}

A $\mathrm{P}_{2}$ fraction was prepared from the whole brain minus cerebellum of 150 - to 250 -gm male Sprague-Dawley rats as described previously (Weiler et al., 1981).

Measurement of Ch uptake and ACh synthesis. The $\mathrm{P}_{2}$ fraction was suspended in Krebs bicarbonate medium with paraoxon $(20 \mu \mathrm{M})$ to a final protein concentration of 0.9 to $1.5 \mathrm{mg} / \mathrm{ml}$. Samples $(4 \mathrm{ml})$ were preincubated in a Dubnoff metabolic shaker at $37^{\circ} \mathrm{C}$ with or without notexin (concentration is indicated under "Results"). After 0,5 , or $10 \mathrm{~min},\left[{ }^{2} \mathrm{H}_{4}\right] \mathrm{Ch}$ was added to each sample and uptake was allowed to continue for $4 \mathrm{~min}$ at $37^{\circ} \mathrm{C}$. The incubation was terminated by pouring samples into prechilled centrifuge tubes $\left(0^{\circ} \mathrm{C}\right)$ and centrifuging at $0^{\circ} \mathrm{C}$ for $10 \mathrm{~min}$ at $10^{4} \times \mathrm{g}$. "Nonspecific" uptake of $\left[{ }^{2} \mathrm{H}_{4}\right] \mathrm{Ch}$ was evaluated using samples kept on ice. All variants of $\mathrm{ACh}$ and $\mathrm{Ch}$ were measured in the supernatant and pellet using a gas chromatographic mass spectrometric assay as described previously (Jenden et al., 1973; Gundersen and Jenden, 1981).

Solutions and chemicals. The normal Krebs bicarbonate medium contained, in millimolar concentrations: $\mathrm{NaCl}, 138 ; \mathrm{KCl}, 5 ; \mathrm{CaCl}_{2}, 2 ; \mathrm{MgCl}_{2}, 1 ; \mathrm{KH}_{2} \mathrm{PO}_{4}, 0.4 ;$ $\mathrm{NaHCO}_{3}, 12$; and glucose, 12. This solution was equilibrated with $95 \% \mathrm{O}_{2}, 5 \% \mathrm{CO}_{2}$ prior to use. Paraoxon was purchased from ICN Pharmaceuticals (Plainview, NY). Notexin was obtained as a gift from Dr. Struan Sutherland (Commonwealth Serum Laboratories, Melbourne, Australia). The toxin was purified from the venom of Notechis scutatus using column chromatography (Sephadex G-75, superfine) followed by two consecutive fractionations on the ion exchange resin Bio-Rex 70. The 
final Bio-Rex fraction was gel filtered using Sephadex G50 (superfine) and the product yielded an $\mathrm{LD}_{\mathrm{i} 0}$ in mice of approximately $15 \mathrm{ng} / \mathrm{gm}$ of body weight (S. Sutherland, personal communication). For our experiments, the toxin was stored $\left(4^{\circ} \mathrm{C}\right)$ as a stock $(1 \mathrm{mg} / \mathrm{ml})$ in $0.9 \%$ saline containing bovine serum albumin $(1 \mathrm{mg} / \mathrm{ml})$. Our determination of the $\mathrm{LD}_{50}$ (intraperitoneal) of notexin in mice gave a value comparable to that communicated by Dr. Sutherland using subcutaneous injection.

Protein was measured by the procedure of Lowry et al. (1951) using bovine serum albumin as a standard. Statistical analyses were performed using the unpaired Student's $t$ test.

\section{Results}

Sen and colleagues (1978) routinely used notexin at a concentration of $0.1 \mu \mathrm{M}$ or approximately $1.28 \mu \mathrm{g} / \mathrm{ml}$. We tested the effect of notexin on cholinergic parameters of rat brain $\mathrm{P}_{2}$ fractions using concentrations of $0.125,1.25$, and $12.5 \mu \mathrm{g} / \mathrm{ml}$. The $\mathrm{P}_{2}$ fraction was incubated with or without the toxin and, after $5 \mathrm{~min},\left[{ }^{3} \mathrm{H}_{4}\right] \mathrm{Ch}(2 \mu \mathrm{M})$ was added to each sample. Incubation continued for $4 \mathrm{~min}$, and after centrifugation, endogenous $\left({ }^{2} \mathrm{H}_{0}\right)$ and deuterium-labeled variants of $\mathrm{ACh}$ and $\mathrm{Ch}$ were assayed in the pellet and medium (Table I).

Each dose of notexin had a somewhat different effect on ACh and Ch metabolism (Table I). Relative to control, the lowest dose of toxin produced no significant change of endogenous ACh $\left(\left[{ }^{2} \mathbf{I}_{0}\right] \mathrm{ACh}\right)$ in either the pellet or medium. Similarly, medium $\left[{ }^{2} \mathrm{H}_{4}\right] \mathrm{ACh}$ was unchanged. However, these samples exhibited a highly significant increase of pellet $\left[{ }^{\prime} \mathrm{H}_{4}\right] \mathrm{ACh}$ such that the sum of pellet plus medium $\left[{ }^{2} \mathrm{H}_{4}\right] \mathrm{ACh}$ was significantly greater than control $(77 \pm 3 \mathrm{pmol} / \mathrm{mg}$ versus $63 \pm 2 \mathrm{pmol} / \mathrm{mg}$ for control; see Table I). This sum of pellet plus medium $\left[{ }^{\prime \prime} \mathrm{H}_{4}\right] \mathrm{ACh}$ can be used as a measure of the quantity of ACh synthesized by the synaptosome fraction during the 4 -min incubation at $37^{\circ} \mathrm{C}$. (The actual amount of ACh synthesized during this period can be computed if the specific activity of the $\left[{ }^{2} \mathrm{H}_{4}\right] \mathrm{Ch}$ precursor is known. The $\left[{ }^{2} \mathrm{H}_{4}\right] \mathrm{Ch}$ specific activity ranged between 0.5 and 0.6 and was unaffected by notexin in these experiments. Thus, we chose not to make this calculation and relied instead on the sum of pellet plus medium $\left[{ }^{2} \mathrm{H}_{4}\right] \mathrm{ACh}$ as an index of ACh synthesis.) Although notexin stimulated ACh synthesis, it did not affect the pellet accumulation of $\left[{ }^{3} \mathrm{H}_{4}\right] \mathrm{Ch}$ (Table I). This indicates that, compared with control, notexin increased the proportion of transported $\left[{ }^{2} \mathrm{H}_{4}\right] \mathrm{Ch}$ that was acetylated.

As with the lower dose, notexin $(1.25 \mu \mathrm{g} / \mathrm{ml})$ significantly increased $\left[{ }^{2} \mathrm{H}_{4}\right] \mathrm{ACh}$ synthesis without altering pellet or medium $\left[{ }^{2} \mathrm{H}_{4}\right] \mathrm{ACh}$ (Table I). However, accompanying this increase of total $\left[{ }^{2} \mathrm{H}_{4}\right] \mathrm{ACh}$ was a marked redistribution of the newly synthesized $\mathrm{ACh}$ between the pellet and medium (Table I). $\left[{ }^{2} \mathrm{H}_{4}\right] \mathrm{ACh}$ output was reduced to $50 \%$ of the control level, while pellet $\left[{ }^{2} \mathrm{H}_{4}\right] \mathrm{ACh}$ was $63 \%$ above control (Table I). This large increase of pellet $\left[{ }^{2} \mathrm{H}_{4}\right] \mathrm{ACh}$ was not accompanied by a proportionate change of pellet $\left[{ }^{2} \mathrm{H}_{4}\right] \mathrm{Ch}$ (Table I). Thus, notexin (1.25 $\mu \mathrm{g} / \mathrm{ml}$ ) enhanced that component of Ch transport which supplies the precursor for ACh synthesis, and simultaneously, it blocked the release of this newly synthesized transmitter.

The highest dose of toxin $(12.5 \mu \mathrm{g} / \mathrm{ml})$ caused a small decline of pellet $\left[{ }^{2} \mathrm{H}_{0}\right] \mathrm{ACh}$ without altering medium $\left[{ }^{2} \mathrm{H}_{0}\right] \mathrm{ACh}$ (Table I). Pellet $\left[{ }^{2} \mathrm{H}_{4}\right] \mathrm{ACh}$ was not significantly different from control, but $\left[{ }^{2} \mathrm{H}_{4}\right] \mathrm{ACh}$ was reduced slightly (Table I). As with the intermediate dose of toxin, there was a substantial reduction of medium $\left[{ }^{2} \mathrm{H}_{4}\right] \mathrm{ACh}$ which contributed to the significant depression of $\left[{ }^{2} \mathrm{H}_{4}\right] \mathrm{ACh}$ synthesis from the control level of $63 \mathrm{pmol} /$ $\mathrm{mg}$ to $48 \mathrm{pmol} / \mathrm{mg}$ (Table I). Thus, this dose of notexin inhibited the uptake and acetylation of $\left[{ }^{2} \mathrm{H}_{4}\right] \mathrm{Ch}$ and reduced the efflux of $\left[{ }^{2} \mathrm{H}_{4}\right] \mathrm{ACh}$.

The last column of Table I illustrates more effectively the inhibition by notexin of $\left[{ }^{2} \mathrm{H}_{4}\right] \mathrm{ACh}$ efflux from synaptosomes. We have computed the percentage of newly synthesized ACh that appeared in the medium of control and toxin-treated preparations. At all three doses of notexin, there was a significant depression of the fractional output of $\left[{ }^{2} \mathrm{H}_{4}\right] \mathrm{ACh}$ relative to control. This inhibition was most pronounced at the intermediate dose $(1.25 \mu \mathrm{g} / \mathrm{ml})$ of toxin which is also where the greatest stimulation of $\left[{ }^{2} \mathrm{H}_{4}\right] \mathrm{ACh}$ synthesis occurred (Table I).

Varying the preincubation protocol. Sen and colleagues (1978) reported an inhibition of $\left[{ }^{3} \mathrm{H}\right] \mathrm{Ch}$ uptake when synaplosomes were resuspended for transport measurements after a 20 -min preincubation with notexin. We

TABLE I

Notexin: Dose response

As described under "Materials and Methods," the P, fraction was incubated with or without notexin at the indicated dose. After 5 min, $\left[{ }^{2} \mathrm{H}_{4}\right] \mathrm{Ch}(2 \mu \mathrm{M})$ was added to each sample and the incubation was continued for $4 \mathrm{~min}$. The uptake was stopped by centrifugation, and endogenous and deuterated variants of $\mathrm{ACh}$ and $\mathrm{Ch}_{1}$ were measured in the pellet and medium. The results are the mean $\pm \mathrm{SE}$ of eight separate determinations.

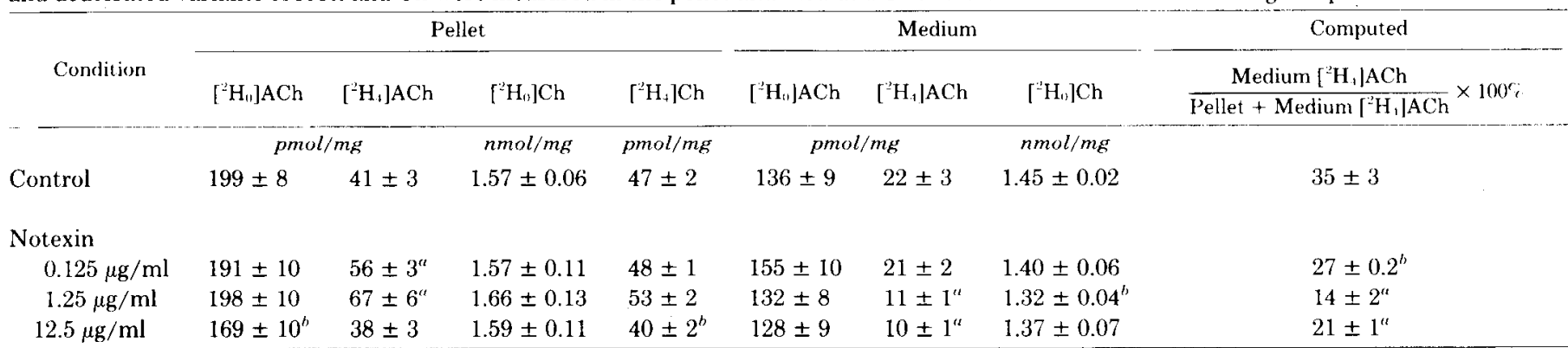

"Difference between the control and toxin-treated preparation is significant at $p<0.01$.

"Difference between the control and toxin-treated preparation is significant at $p<0.05$. 
investigated whether different preincubation protocols would alter the effects of notexin $(1.25 \mu \mathrm{g} / \mathrm{ml})$ on the ACh synthesis and release reported in Table I.

The experiments of Table II employed the same protocol as those of Table I, but preincubation was for 0,5 , or $10 \mathrm{~min}$ and the concentration of notexin was $1.25 \mu \mathrm{g} /$ ml. Relative to control, samples with no preincubation showed an increase of pellet $\left[{ }^{2} \mathrm{H}_{4}\right] \mathrm{ACh}$ and a small decline of medium $\left[{ }^{2} \mathbf{H}_{4}\right] \mathrm{ACh}$ when exposed to notexin (Table II), but no other parameter was changed significantly (Table II).

The data for samples preincubated for $5 \mathrm{~min}$ with notexin (Table II) are similar to those given in Table I. However, preparations that were preincubated with notexin for $10 \mathrm{~min}$ prior to the beginning of $\left[{ }^{2} \mathrm{H}_{4}\right] \mathrm{Ch}$ uptake showed no stimulation by the toxin of $\left[{ }^{2} \mathrm{H}_{4}\right] \mathrm{ACh}$ synthesis (pellet plus medium). Moreover, efflux of both $\left[{ }^{2} \mathrm{H}_{0}\right] \mathrm{ACh}$ and $\left[{ }^{2} \mathrm{H}_{4}\right] \mathrm{ACh}$ were depressed significantly (Table II). These data are consistent with a short-lived effect of notexin to stimulate ACh synthesis, and while the inhibition of $\left[{ }^{2} \mathrm{H}_{4}\right] \mathrm{ACh}$ efflux is evident without any toxin pretreatment (Table II), longer preincubations are necessary to observe a reduction of $\left[{ }^{2} \mathrm{H}_{0}\right] \mathrm{ACh}$ output.

The last set of experiments that we performed followed a protocol similar to that of Sen et al. (1978). Synaptosomes were preincubated $\left(4 \mathrm{~min}\right.$ at $\left.37^{\circ} \mathrm{C}\right)$ with notexin $(0.125$ or $1.25 \mu \mathrm{g} / \mathrm{ml})$ in a Krebs medium containing paraoxon $(20 \mu \mathrm{M})$ and then centrifuged and resuspended at $4^{\circ} \mathrm{C}$ in the same medium containing $\left[{ }^{2} \mathrm{H}_{4}\right] \mathrm{Ch}$ but no additional toxin. After resuspension, samples were either centrifuged immediately or incubated for $4 \mathrm{~min}$ at $37^{\circ} \mathrm{C}$. We found that control samples which had been centrifuged immediately after resuspension lost about $12 \%$ of their total $\mathrm{ACh}$ into the medium. However, the nolexintreated preparations released 40 to $50 \%$ of their total $\mathrm{ACh}$ into the medium. This result suggests that the notexin-treated synaptosomes were disrupted during the resuspension procedure that preceded the second incubation and that up to half of the ACh-containing particles had lysed. These results are consistent with the evidence of Sen et al. (1978), who showed that resuspension of notexin-treated synaptosomes resulted in the release of the cytoplasmic enzyme, lactate dehydrogenase, as well as morphological signs of synaptosomal lysis. We confirmed the findings of Sen et al. (1978) that these toxintreated preparations were deficient in their ability to transport and acetylate medium Ch (data not shown).

\section{Discussion}

The data presented in this communication indicate that notexin stimulates the synthesis of ACh and simultaneously blocks the spontaneous release of this newly synthesized ACh. Because there remains considerable debate regarding the mechanistic implications of phenomena such as the spontaneous efflux of ACh from cholinergic preparations (see Katz and Miledi, 1977, for a discussion) and the preferential release of newly synthesized ACh (see Weiler et al., 1981), we cannot provide a rigorous explanation for the actions of notexin. However, we speculate that our observations reflect a primary action of notexin to inhibit the translocation of $\mathrm{ACh}$ to release sites (e.g., by inhibiting vesicle recycling as proposed by Cull-Candy et al. (1976) or by inhibiting the loading of ACh into vesicles). Moreover, if the concentration of $\mathrm{ACh}$ at the release sites controls the rate of transmitter synthesis, then a reduction by notexin of the ACh level at these points would result in an increase of ACh synthesis. This would produce the observed increases of pellet $\left[{ }^{2} \mathrm{H}_{4}\right] \mathrm{ACh}$ (Tables I and II). These postulates may be scrutinized profitably employing systems such as Torpedo electroplax which can be fractionated to yield well characterized subcellular components (e.g., Zimmermann and Denston, 1977).

An essential feature of our results is the extent to which the observations are dependent on the experimental protocol. This fact helps to explain the discrepancy between our findings (see also Gundersen and Jenden, 1981) and those of Sen et al. (1978). The stimulation by notexin of ACh synthesis is most apparent using doses of the toxin in the range of $1 \mu \mathrm{g} / \mathrm{ml}$ and a total time of exposure of 5 to $10 \mathrm{~min}$ (Tables I and II). Using a preincubation of $10 \mathrm{~min}$, notexin still causes an increase

TABLE II

Varying length of preincubation with notexin

The experimental protocol was the same as that described in Table I except the concentralion of notexin was $1.25 \mu \mathrm{g} / \mathrm{ml}$ and the preincubation time was 0,5 , or $10 \mathrm{~min}$. Results are the mean $\pm \mathrm{SE}$ of $n$ separate incubations.

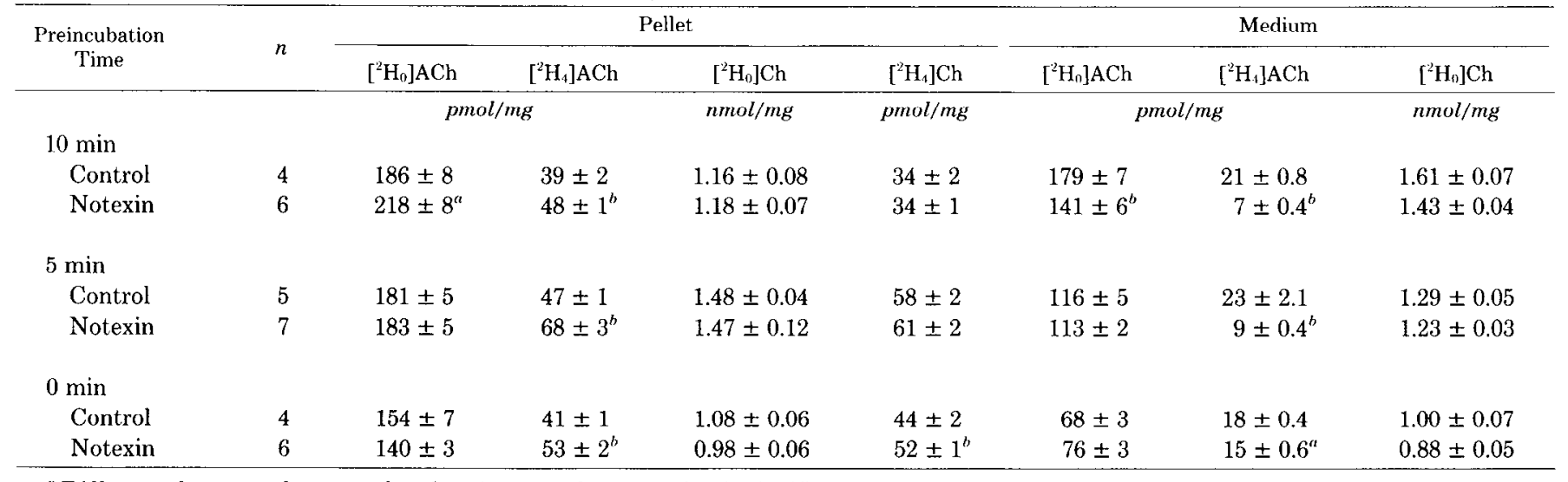

${ }^{a}$ Difference between the control and toxin-treated preparation is significant at $p<0.05$.

${ }^{b}$ Difference between the control and toxin-treated preparation is significant at $p<0.01$. 
of pellet $\left[{ }^{2} \mathrm{H}_{4}\right] \mathrm{ACh}$, but total $\left[{ }^{2} \mathrm{H}_{4}\right] \Lambda \mathrm{Ch}$ (pellet plus medium) is not increased relative to control (Table II). This suggests that notexin produces a transient perturbation of the mechanism regulating $\mathrm{ACh}$ synthesis and that this effect is obscured when higher doses or longer periods of incubation are used. Since Sen et al. (1978) routinely used preincubation conditions that exceeded $10 \mathrm{~min}$ and that resulted in the lysis of synaptosomes, they would not have observed the initial stimulatory effect of notexin obtained in these experiments. In a related context, we note that Dowdall and colleagues (1977) reported an inhibition by notexin of $\left[{ }^{3} \mathrm{H}\right] \mathrm{Ch}$ transport by Torpedo $\mathrm{t}$ sacs. However, they found in a subsequent investigation (Dowdall et al., 1979) that notexin actually stimulated (a $24 \%$ increase of $\left[{ }^{3} \mathrm{H}\right] \mathrm{Ch}$ uptake was recorded) or had no effect on $\left[{ }^{3} \mathrm{H}\right] \mathrm{Ch}$ uptake by purified synaptosomal preparations from guinea pig brain or squid optic lobe. This seeming inconsistency of results appeared to depend on the type of preparation and the dose and time of exposure to notexin. This supports our contention (and a similar one made by Dowdall et al., 1979) of the critical role of these parameters in determining which effects of notexin are observed in a specific experiment. Thus, notexin may be valuable as a probe of mechanisms regulating ACh synthesis and release as long as conditions are optimized to exclude its destructive effects on the preparation.

\section{References}

Chang, C. C., J. D. Lee, D. Eaker, and J. Fohlman (1977) The presynaptic neuromuscular blocking action of taipoxin. A comparison with $\beta$-bungarotoxin and crotoxin. Toxicon 15: 571-576.

Cull-Candy, S. G., J. Fohlman, D. Gustavsson, R. LullmanRauch, and S. Thesleff (1976) The effects of taipoxin and notexin on the function and fine structure of the murine neuromuscular junction. Neuroscience 1: 175-180.

Dowdall, M. J., J. Fohlman, and D. Eaker (1977) Inhibition of high affinity choline transport in peripheral cholinergic end- ings by presynaptic snake venom neurotoxins. Nature 269 : $700-702$.

Dowdall, M. J., J. Fohlman, and A. Watts (1979) Presynaptic action of snake venom neurotoxins on cholinergic systems. Adv. Cytopharmacol. 3: 63-76.

Gundersen, C. B., and D. J. Jenden (1981) Alterations of acetylcholine and choline metabolism in mammalian preparations treated with $\beta$-bungarotoxin. J. Neurochem. 36: 938948.

Howard, B. D., and C. B. Gundersen (1980) Effects and mechanisms of presynaptically acting polypeptide neurotoxins. Annu. Rev. Pharmacol. Toxicol. 20: 307-336.

Jenden, D. J., M. Roch, and R. B. Booth (1973) Simultaneous measurement of endogenous and deuterium labelled tracer variants of choline and acetylcholine in subpicomole quantities by gas chromatography mass spectrometry. Anal. Biochem. 55: 438-448.

Katz, B., and R. Miledi (1977) Transmitter leakage from nerve endings. Proc. R. Soc. Lond. (Biol.) 196: 59-72.

Lee, C. Y. (1979) Recent advances in the chemistry and pharmacology of snake toxins. Adv. Cytopharmacol. 3: 1-16.

Lowry, O. H., N. J. Rosebrough, A. L. Farr, and R. J. Randall (1951) Protein measurements with the Folin phenol reagent. J. Biol. Chem. 193: 265-275.

Magazanik, L. G., and T. I. Slavnova (1978) Effects of presynaptic polypeptide neurotoxins from tiger snake venom (notechis II-5 and notexin) on frog neuromuscular junction. Physiol. Bohemoslov. 27: 421-429.

Sen, I., P. A. Grantham, and J. R. Cooper (1976) Mechanism of action of $\beta$-bungarotoxin on synaptosomal preparations. Proc. Natl. Acad. Sci. U. S. A. 73: 2664-2668.

Sen, I., A. Baba, R. A. Schulz, and J. R. Cooper (1978) Mechanism of action of notexin and notechis II-5 on synaptosomes. J. Neurochem. 31: 969-976.

Weiler, M. H., C. B. Gundersen, and D. J. Jenden (1981) Choline uptake and acetylcholine synthesis in synaptosomes: Investigations using two differently labelled variants of choline. J. Neurochem. 36: 1802-1812.

Zimmermann, H., and C. R. Denston (1977) Separation of synaptic vesicles of different functional states from cholinergic synapses of the Torpedo electric organ. Neuroscience 2: $715-730$. 